\title{
Removal of Lead from Water Using Calcium Alginate Beads Doped with Hydrazine Sulphate-Activated Red Mud as Adsorbent
}

\author{
A. Naga Babu, G. V. Krishna Mohan, K. Kalpana, and K. Ravindhranath \\ Department of Chemistry, K L University, Green Fields, Vaddeswaram, Guntur, 522502, India \\ Correspondence should be addressed to K. Ravindhranath; ravindhranath.kunta@gmail.com
}

Received 26 August 2017; Revised 10 October 2017; Accepted 25 October 2017; Published 31 December 2017

Academic Editor: Guido Crisponi

Copyright (c) 2017 A. Naga Babu et al. This is an open access article distributed under the Creative Commons Attribution License, which permits unrestricted use, distribution, and reproduction in any medium, provided the original work is properly cited.

Calcium alginate beads doped with hydrazine sulphate-treated red mud are investigated as adsorbent for extracting lead ions from water using batch methods of extraction. Different extraction conditions are optimised for maximum lead extraction. Substantial amount of lead is removed, and the adsorption ability is found to be $138.6 \mathrm{mg} / \mathrm{g}$. Surface characterization using FTIR, EDX, and FESEM confirms that lead is "onto" the surface of the adsorbent. Thermodynamic parameters, adsorption isotherms, and kinetics of adsorption are analysed. Adsorption is "physisorption" in nature and spontaneous. The adsorbent developed can be regenerated using $0.1 \mathrm{M} \mathrm{HCl}$. Thus regenerated adsorbent can be used as the adsorbent for further removal of lead at least 10 times, and this enables the complete removal of lead from water by repetitive use of the regenerated adsorbent. The beads facilitate the easy filtration. The methodology developed is successfully applied for removing lead from industrial waste waters.

\section{Introduction}

The consumption of water containing lead ions is hazardous, and it is reported that it causes various ailments such as kidney and neurological problems, anaemia, brain hemorrhage, and even death $[1,2]$. The maximum permissible limit is $10 \mathrm{ppb}$ (WHO), and presently, zero lead concentration of waters is preferred [3]. Further, the lead is not biodegradable, and hence, the problems are amplified.

Intensive investigations are being carried out throughout the globe to remove lead from the waters and they have one or other disadvantage, and a globally acceptable eco-friendly, economical, and effective method is still eluding the researcher. In this contest, the unconventional methods are attracting the researchers. Our research group has developed some methodologies based on adsorbents derived from biomaterials for removing various polluting ions such as chromium (VI) $[4,5]$, zinc [6], aluminium (III) [7], fluoride [8, 9], nitrite [10], ammonia [11], phosphate [12], and dyes [13] from water.

Red mud is a waste product from aluminium industries, and its adsorption nature towards various pollutants is being investigated [14-18]. The uses of treated red mud in the removal of lead are reported in the literature. $\mathrm{HCl}$-activated red mud is found to have an adsorption capacity of $6.207 \mathrm{mg} / \mathrm{g}$ at $\mathrm{pH} 4$ and other optimum conditions of extraction [19]. Hydrogen peroxide-activated red mud is found to have an adsorption capacity of $64.79 \mathrm{mg} / \mathrm{g}$ at $\mathrm{pH} 6$ [20]. Heat-activated red mud at $700^{\circ} \mathrm{C}$ is found to have an adsorption capacity of $38.2 \mathrm{mg} / \mathrm{g}$ at $\mathrm{pH} 4$ [21]. Red mud coagulant is used to remove lead ions at $\mathrm{pH} 7$, and its sorption ability is reported as $98.695 \mathrm{mg} / \mathrm{g}$ [22]. Zirconium-treated fine red mud impregnated in $\mathrm{Zn}$-alginate beads (ZRMAB) is investigated for their adsorption nature towards phosphate from water, and its sorption ability for phosphates is found to be $13.64 \mathrm{mg} / \mathrm{g}$ of the adsorbent [23]. Organically modified magnesium silicate nanocomposites are also used for the removal of lead ions from water [24].

In this investigation, an adsorbent is prepared by doping hydrazine sulphate-treated red mud in calcium alginate beads, and its adsorption nature towards lead ions is studied. The present developed adsorbent is found to have $138.6 \mathrm{mg} / \mathrm{g}$ adsorption capacity towards $\mathrm{Pb}^{2+}$ ions, and further, the entrapping of the adsorbent in the beads facilitates the easy filtration. 
TABLe 1: Chemical properties of red mud.

\begin{tabular}{lc}
\hline Parameter & Result (\%) \\
\hline Alumina as $\mathrm{Al}_{2} \mathrm{O}_{3}$ & 15.47 \\
Iron as $\mathrm{Fe}_{2} \mathrm{O}_{3}$ & 58.78 \\
Silica as $\mathrm{SiO}_{2}$ & 6.58 \\
Titanium as $\mathrm{TiO}_{2}$ & 4.39 \\
Soda as $\mathrm{Na}_{2} \mathrm{O}$ & 3.63 \\
Calcium as $\mathrm{CaO}$ & 1.49 \\
Phosphorus as $\mathrm{P}_{2} \mathrm{O}_{5}$ & 0.159 \\
Vanadium as $\mathrm{V}_{2} \mathrm{O}_{5}$ & 0.110 \\
Loss of ignition $\left(105-1000^{\circ} \mathrm{C}\right)$ & 7.22 \\
\hline
\end{tabular}

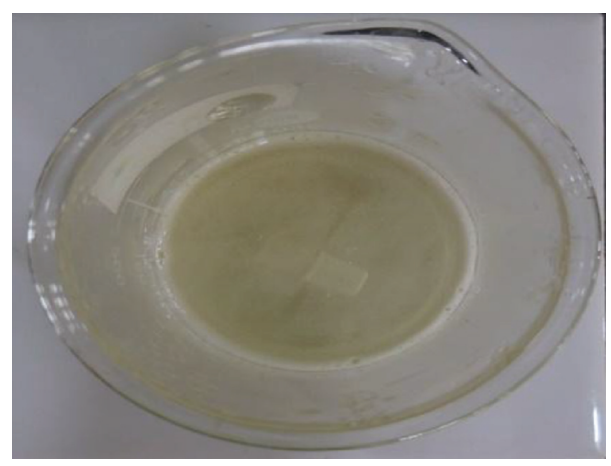

(a)

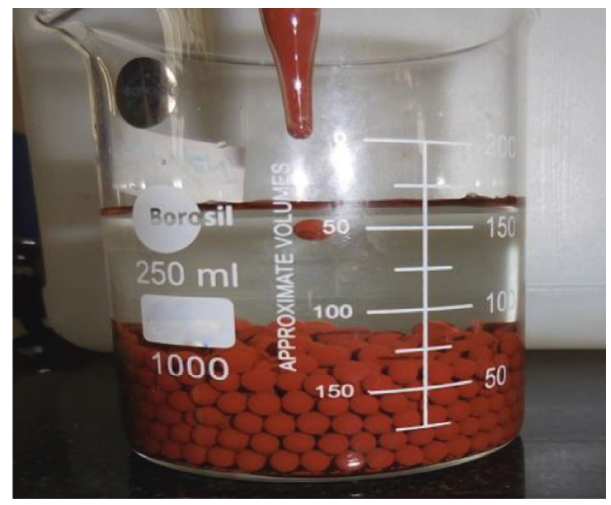

(c)

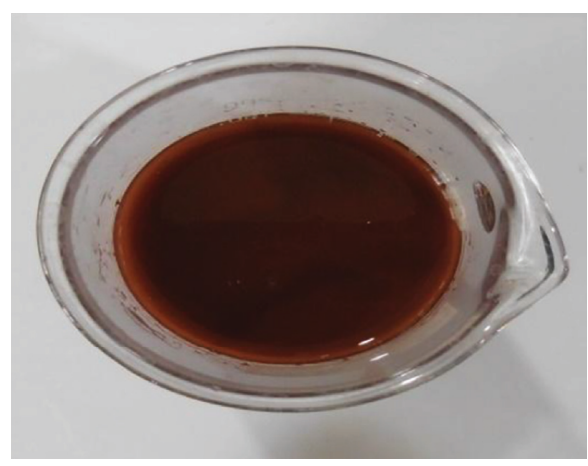

(b)

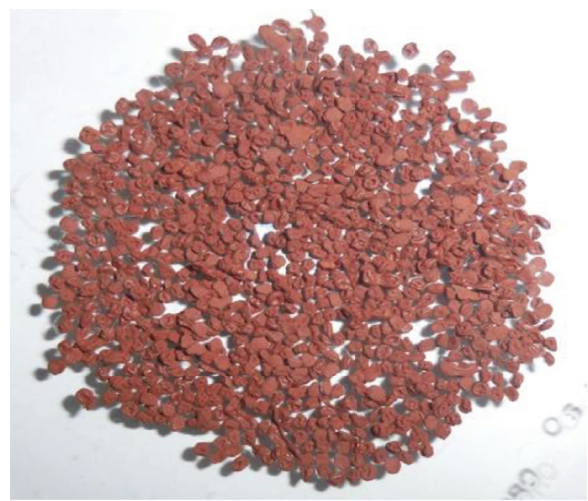

(d)

FIGURE 1: Hydrazine sulphate-treated calcium alginate beads. (a) 3.0\% sodium alginate solution. (b) Treated red mud and sodium alginate mixture. (c) Formation of Ca-alginate beads doped with treated red mud. (d) Dried adsorbent (HRMCAB) at $343 \mathrm{~K}$ used for investigation.

\section{Materials and Methods}

2.1. Chemicals. The AR grade chemicals, namely, lead nitrate, sodium alginate, calcium chloride, nitric acid, hydrochloric acid, and sodium hydroxide, were purchased from SD Fine Chemicals Pvt. Ltd. and Merck \& Co. Double distilled water was used for preparation of solutions.

2.2. Adsorbent. The red mud was obtained from Vedanta Aluminium Ltd., Utkal Alumina, Lanjigarh Refinery, Rayagada,
Orissa, and the chemical composition of the raw red mud was presented in Table 1.

2.3. Treatment. The collected raw red mud sample was repeatedly washed with distilled water till the washings were neutral to $\mathrm{pH}$ and dried for two hours at $378 \mathrm{~K}$. Then, the red mud was grounded and sieved to $75 \mu$. Thus obtained fine red mud was mixed with $1 \%$ hydrazine sulphate solution in $1: 2$ (w/w) ratio, and the resulting solution was boiled for $2 \mathrm{hrs}$. Then, the red mud was filtered, repeatedly washed with double 

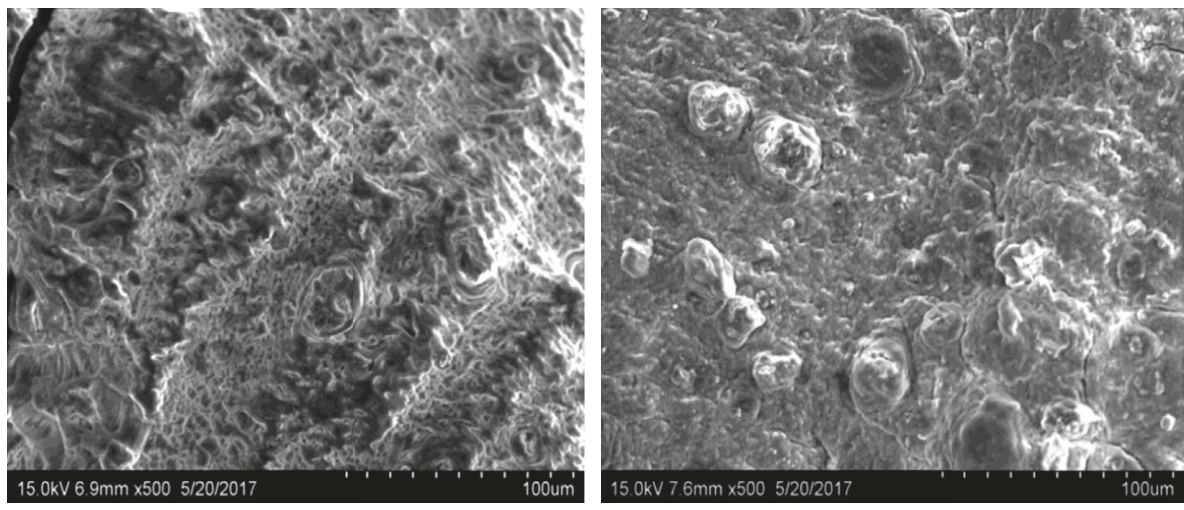

(a)
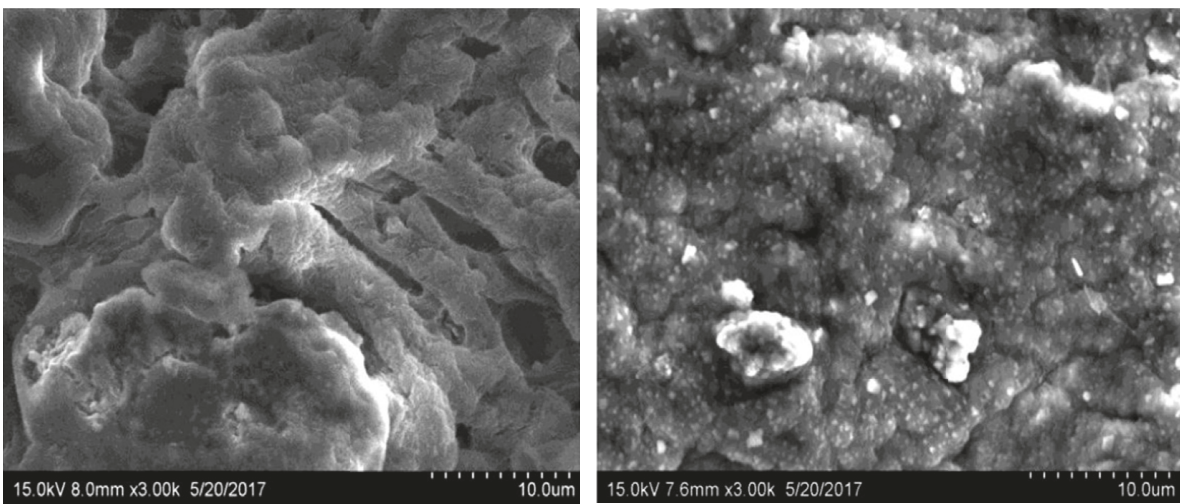

(b)

Figure 2: SEM images of adsorbent (HRMCAB). (a) SEM images of adsorbent before (left) and after (right) lead adsorption at 500x resolution. (b) SEM images of adsorbent before (left) and after (after) lead adsorption at 3000x resolution.

distilled water, dried in hot-air oven at $378 \mathrm{~K}$ for two hours, and then stored in airtight coloured bottle for further work.

2.4. Immobilization of Treated Fine Red Mud in Calcium Alginate Beads. A $100 \mathrm{~mL}$ of double distilled water was taken in a $250 \mathrm{~mL}$ beaker and to it, $3.0 \mathrm{~g}$ of sodium alginate powder was slowly added by continuous stirring at $363 \mathrm{~K}$ temperature and maintaining $1000 \mathrm{rpm}$ until the solution was homogeneous and clear. Then, $0.1 \mathrm{~g}$ of hydrazine sulphatetreated red mud was slowly added to it by constant stirring, and the resulting mixture was cooled to room temperature. Then, this solution was dropwisely added to a supercooled $\left(-2^{\circ} \mathrm{C}\right) 2 \%$ calcium chloride solution by maintaining uniform size of beads. The beads thus formed were filtered, repeatedly washed with distilled water for removing any remaining $\mathrm{CaCl}_{2}$ on beads, dried at $343 \mathrm{~K}$, and stored in a coloured bottle (Figure 1).

2.5. Surface Characterization. FESEM images of the adsorbent (HRMCAB) were taken by using HITACHI S3700N SEM instrument manufactured by HITACHI HighTechnologies Ltd., India. The magnifications from 500 to $15,000 \mathrm{x}$ and accelerating voltage of $15,000 \mathrm{~V}$ were maintained while taking the SEM images, and the images are presented in Figure 2.

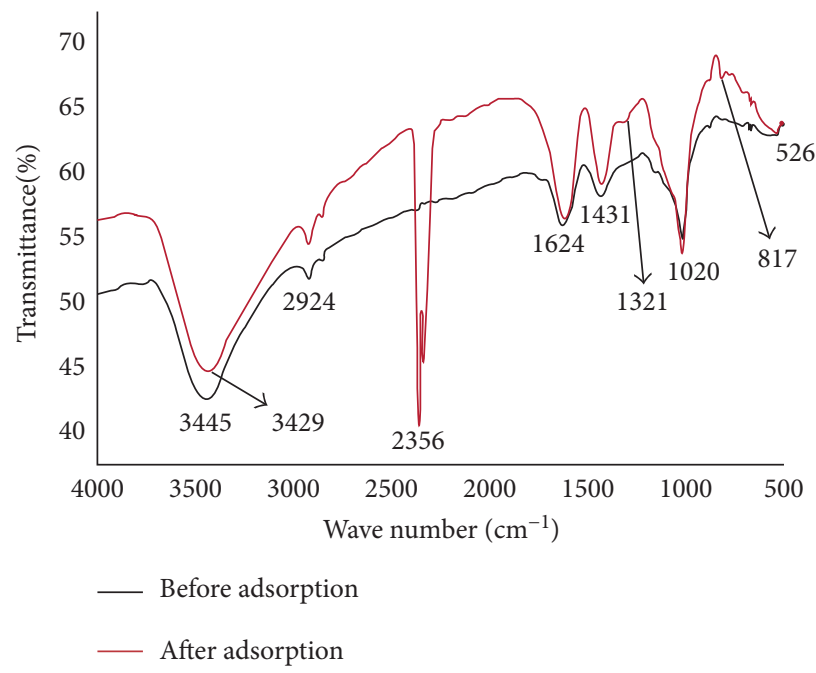

FigURE 3: FTIR spectra of adsorbent (HRMCAB).

FTIR spectra of HRMCAB (before and after adsorption) were recorded using Shimadzu (8400S) FTIR Spectrophotometer. The spectrum was recorded by adopting the $\mathrm{KBr}$ pellet method in the range 4000 to $500 \mathrm{~cm}^{-1}$ at room temperature and at optical resolution of $4(1 / \mathrm{cm})$. The observed spectrum is presented in Figure 3. 


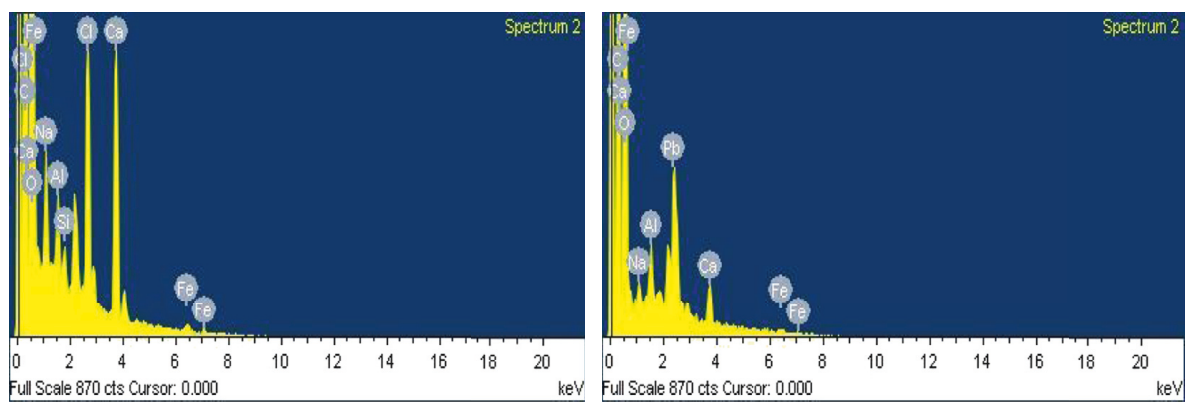

Figure 4: EDX spectra of adsorbent (HRMCAB) before and after adsorption of lead.

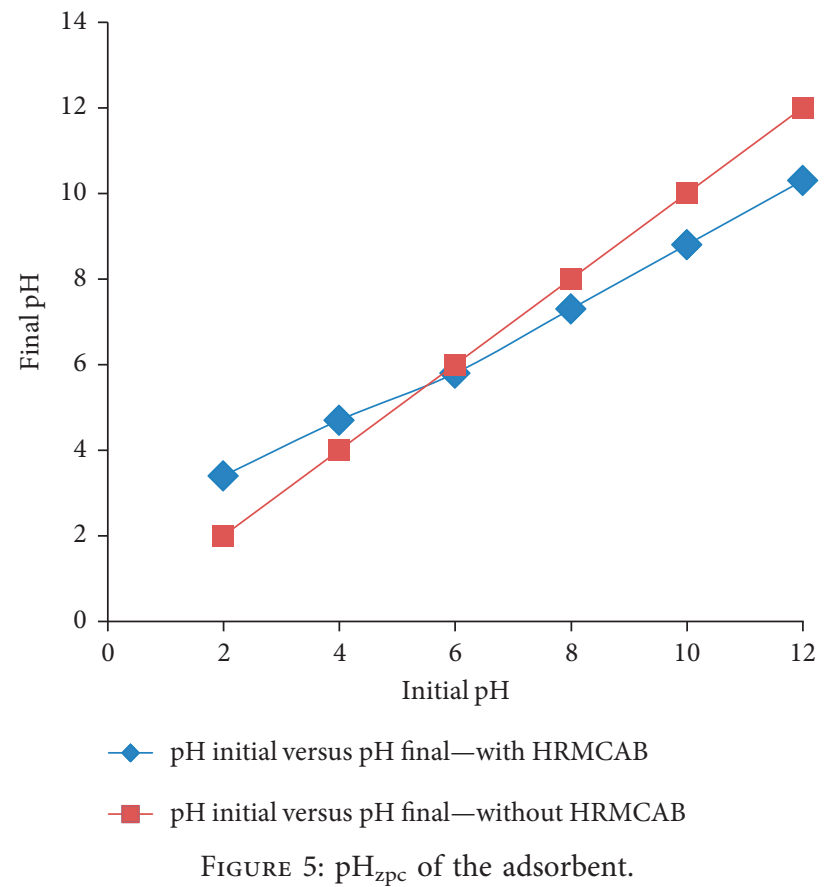

EDX spectrum of the adsorbent before and after adsorption of lead was recorded by using Hitachi (S-3700N) EDX detector and is presented in Figure 4.

By adopting the $\mathrm{pH}$ equilibrium method $[25,26], \mathrm{pH}_{\mathrm{ZPC}}$ of the adsorbent (HRMCAB) was determined by using Hanna pH meter, model HI2211-02, and the obtained plot is presented in Figure 5.

2.6. Method. Batch modes of extractions were adopted [27-29]. $100 \mathrm{~mL}$ of $100 \mathrm{mg} / \mathrm{L}$ lead solution was taken in $250 \mathrm{~mL}$ conical flasks and to it, different quantities of adsorbent $(0.5$ to $3 \mathrm{~g}$ ) were added. Then, using $0.1 \mathrm{M} \mathrm{HCl}$ and $0.1 \mathrm{M} \mathrm{NaOH}$ solutions, the pHs were adjusted to 2 to 12 , and the conical flasks were shaken using the orbital shaker at $300 \mathrm{rpm}$ for $240 \mathrm{~min}$ at $303 \mathrm{~K}$. After the completion of the required time, the conical flasks were removed, and their contents were filtered. The remaining $\mathrm{Pb}^{2+}$ ions in the solution were analysed by atomic adsorption spectroscopy (AA 500) at different parameters such as measure method: flame absorption, wavelength:
$217.00 \mathrm{~nm}$, slit: $0.4 \mathrm{~nm}$, high voltage: $416.25 \mathrm{~V}$, lamp current: $5.0 \mathrm{~mA}$, and fuel flow rate: $1200 \mathrm{~mL} / \mathrm{min}$.

The percentage removal of lead and adsorbed amount of lead was calculated by using the following equations. Adsorbed amount:

$$
\left(q_{e}\right)=\frac{\left(C_{i}-C_{e}\right)}{m} V,
$$

percentage removal:

$$
(\% R)=\frac{\left(C_{i}-C_{e}\right)}{C_{i}} 100,
$$

where $C_{i}$ is the initial $\mathrm{Pb}^{2+}$ concentration $(\mathrm{mg} / \mathrm{L}), C_{e}$ is the $\mathrm{Pb}^{2+}$ concentration at equilibrium $(\mathrm{mg} / \mathrm{L}), V$ is the volume of $\mathrm{Pb}^{2+}$ solution (simulated) in litres, and $m$ is the mass of the adsorbent in grams.

The same procedure was adopted in finding the effect of the various physicochemical parameters on the extraction of $\mathrm{Pb}^{2+}$ "onto" the surface of HRMCAB. The results are presented in Figures 1-9 and Tables 2-4. 

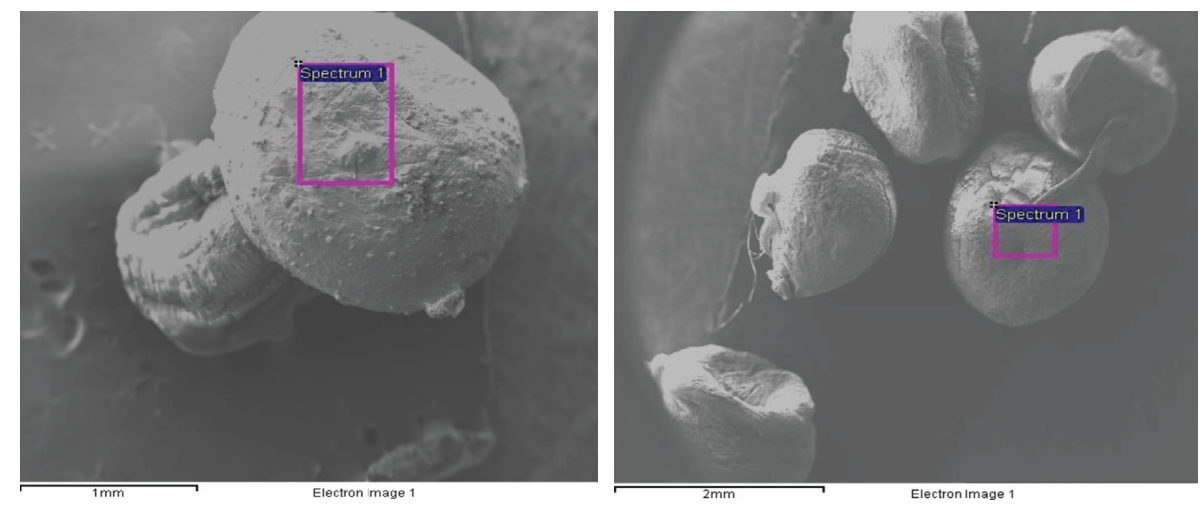

FIgURE 6: Electronic images of the adsorbent (HRMCAB) before and after lead adsorption.

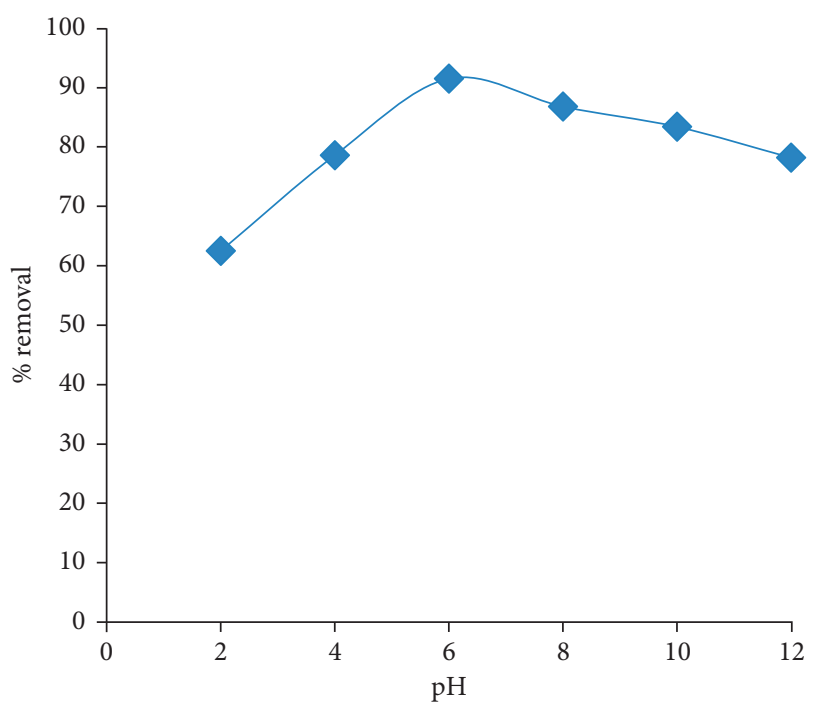

FiguRE 7: Effect of $\mathrm{pH}$ on adsorption of lead.

\section{Results and Discussion}

The raw red mud composition is presented in Table 1. It mainly consists of alumina, iron oxide, $\mathrm{SiO}_{2}, \mathrm{Na}_{2} \mathrm{O}, \mathrm{CaO}$, and traces of $\mathrm{P}$ and $\mathrm{V}$. The red mud is treated with hydrazine sulphate and is doped in calcium alginate beads. Thus obtained beads (HRMCAB) are characterized and studied for its adsorption nature towards lead ions from water. The results are presented below.

\subsection{HRMCAB Characterization}

3.1.1. FESEM. FESEM images of the adsorbent (HRMCAB) before and after equilibration are noted and presented in Figure 2. It can be observed in SEM images that the adsorbent surface have many pores, edges, cavities, and corners before equilibration. Further, some crystalline aggregates are present, indicating different mineral phases such as gibbsite, goethite, and hematite.

After equilibration of the adsorbent with waters containing lead ions, there is an emphatic change on the SEM photographs. The pores and cavities are clogged, edges

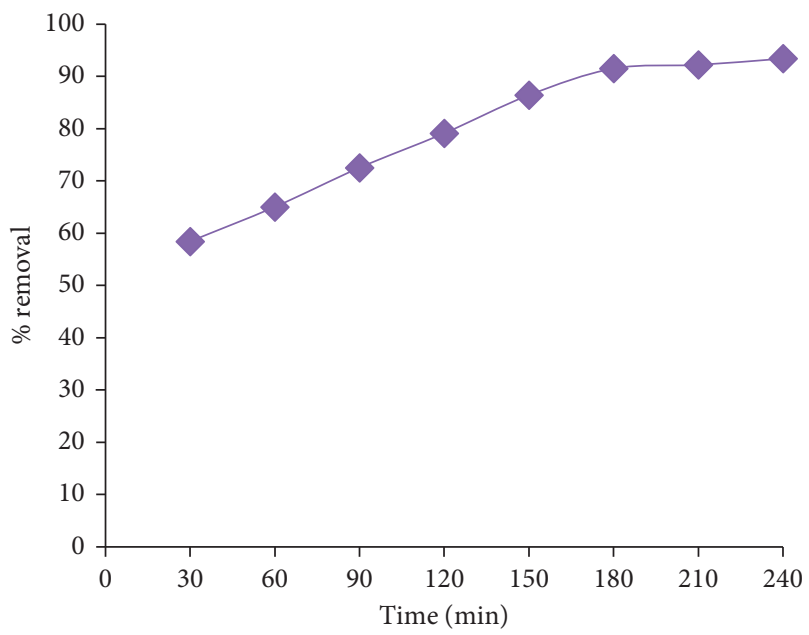

Figure 8: Effect of contact time on adsorption of lead.

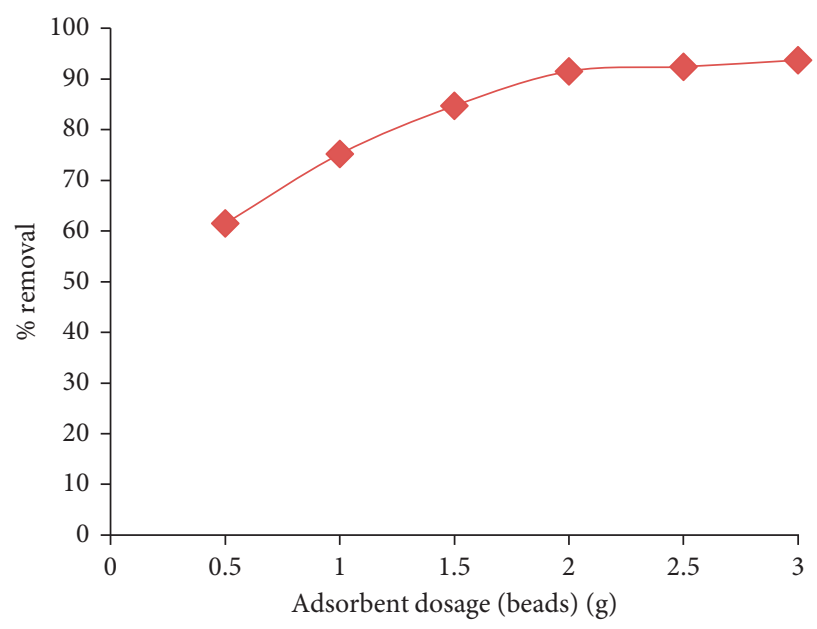

Figure 9: Effect of sorbent dosage on adsorption of lead.

disappeared, and phase boundaries are blurred. Further, some shiny patches appeared. All these changes in the surface features of the adsorbent indicate that the lead is "onto" the surface of the adsorbent.

Moreover, the electronic images presented in Figure 6 also indicate that the lead is present on the adsorbent surface. 
TABLE 2: Thermodynamic parameters of adsorption of the lead on HRMCAB.

\begin{tabular}{|c|c|c|c|c|c|c|}
\hline$T(K)$ & $K_{d}(\mathrm{~L} / \mathrm{g})$ & Vant Hoff equation: $\ln \left(K_{d}\right)=\left(\Delta S^{0} / R\right)-\left(\Delta H^{0} / R T\right)$ & $\Delta H(\mathrm{~kJ} / \mathrm{mole})$ & $\Delta S(\mathrm{~J} / \mathrm{mole})$ & $R^{2}$ & $\Delta G(\mathrm{~kJ} / \mathrm{mole})$ \\
\hline 303 & 16.30 & \multirow{4}{*}{$y=-9581 x+34.078$} & \multirow{4}{*}{79.656} & \multirow{4}{*}{283.32} & \multirow{4}{*}{0.9013} & -6.189 \\
\hline 313 & 22.92 & & & & & -9.022 \\
\hline 323 & 52.59 & & & & & -11.855 \\
\hline 333 & 301.51 & & & & & -14.689 \\
\hline
\end{tabular}

TABle 3: Adsorption parameters.

\begin{tabular}{|c|c|c|c|c|c|}
\hline S. number & Adsorption isotherms & - & Slope & Intercept & $R^{2}$ \\
\hline$\overline{(1)}$ & Freundlich isotherm & - & 0.0894 & 2.0781 & 0.9662 \\
\hline (2) & Langmuir isotherm & $R_{\mathrm{L}}=0.0133$ & 0.0057 & 0.0077 & 0.9996 \\
\hline (3) & Temkin isotherm & $B=12.701$ & 12.701 & 119.97 & 0.9603 \\
\hline$(4)$ & Dubinin-Radushkevich isotherm & $E=0.408$ & $-3 E-06$ & 5.1485 & 0.9841 \\
\hline
\end{tabular}

TABle 4: Adsorption kinetic parameters.

\begin{tabular}{|c|c|c|c|c|}
\hline S. number & Adsorption kinetic parameters & Slope & Intercept & $R^{2}$ \\
\hline (1) & Pseudo-first-order model & -0.0103 & 2.234 & 0.8373 \\
\hline (2) & Pseudo-second-order model & 0.0062 & 0.2181 & 0.9934 \\
\hline (3) & Elovich model & 28.253 & -12.52 & 0.9654 \\
\hline$(4)$ & Bangham's pore diffusion model & 0.2563 & -1.9726 & 0.9768 \\
\hline
\end{tabular}

3.1.2. FTIR. The FTIR spectrum of the adsorbent (before and after adsorption of the lead) is presented in Figure 3.

The band pertaining to the stretching - $\mathrm{OH}$ group of silanol groups and also adsorbed water appeared at $3445 \mathrm{~cm}^{-1}$ as broad band in the before adsorption spectrum. In the after adsorption spectrum, this band is shifted to $3429 \mathrm{~cm}^{-1}$. The bending vibrations of $-\mathrm{OH}$ are assigned to the peak at $1624 \mathrm{~cm}^{-1}$ in both before and after adsorption spectra, and there is no change in their position. The peaks at $1020 \mathrm{~cm}^{-1}$ and $526 \mathrm{~cm}^{-1}$ in both spectra can be assigned to $\mathrm{Al}-\mathrm{O}-\mathrm{Si}$ (symmetric), $\mathrm{Si}-\mathrm{O}-\mathrm{Si}$ (asymmetric), and $\mathrm{Fe}-\mathrm{O}$ stretching vibrations. The drastic difference in the spectral peaks before and after adsorption of lead could be seen in the appearance of an intensive band at $2356 \mathrm{~cm}^{-1}$ and small peaks at $1321 \mathrm{~cm}^{-1}$ and $817 \mathrm{~cm}^{-1}$ in the after adsorption spectrum. These features indicate that the lead is "onto" the surface of the adsorbent (HRMCAB).

3.1.3. EDX Spectrum. The EDX spectra of adsorbent (HRMCAB) before and after adsorption of lead are presented in Figure 4. The presence of lead peak in the spectrum taken after adsorption equilibration and its absence before adsorption indicate that the lead ions are successfully adsorbed "onto" the surface of the adsorbent (HRMCAB).

3.2. Influence of Various Physicochemical Parameters. The sorption ability of the adsorbent (HRMCAB) towards $\mathrm{Pb}^{2+}$ is investigated using simulated waters containing $\mathrm{Pb}^{2+}$ and varying different physicochemical conditions, namely, $\mathrm{pH}$, equilibration time, adsorbent dosage, initial $\mathrm{Pb}^{2+}$ concentration, temperature, and interfering co-ions. The results obtained are presented below.

3.2.1. Effect of $p H$. Behaviour of the adsorbent (HRMCAB) towards lead ions mainly depends upon the solution $\mathrm{pH}$. Hence, by varying the $\mathrm{pH}$ from 2.0 to 12.0 , the optimum $\mathrm{pH}$ for the successful removal of lead is investigated while keeping the other conditions of extraction at other ideal levels, namely, sorbent dosage: $20 \mathrm{~g} / \mathrm{L}$, agitation time: $180 \mathrm{~min}$, rpm: 300, initial concentration: $100 \mathrm{mg} / \mathrm{L}$, and temperature: $303 \mathrm{~K}$. The results are presented in Figure 7.

It can be seen from Figure 7 that the maximum removal of $\mathrm{Pb}^{2+}$ to an extent of $91.5 \%$ can be removed at $\mathrm{pH}$ 6. But, as the $\mathrm{pH}$ is increased to 8,10 , and 12 , the \% removal decreased to $86.8 \%, 83.4 \%$, and $78.2 \%$, respectively. But, as the $\mathrm{pH}$ is decreased to 4 and 2, the \% removal is decreased to $78.6 \%$ and $62.5 \%$, respectively. It can be seen that on the acidic side of the $\mathrm{pH}$, the fall of \% removal is more pronounced than on the basic side. These observations can be accounted from the view point of $\mathrm{pH}_{\mathrm{ZPC}}$ and the speciation of $\mathrm{Pb}^{2+}$ ion at various $\mathrm{pHs}$. From Figure 5, it may be inferred that $\mathrm{pH}_{\mathrm{ZPC}}$ is 5.8 , and hence, at this $\mathrm{pH}$, no ionic thrust prevails on HRMCAB surface. Below this $\mathrm{pH}$, protonation to surface hydroxyl groups of HRMCAB occurs, thereby imparting +ve charge to the surface. The lead species in acidic conditions is $\mathrm{Pb}^{2+}$, and as it is a cation, it is to compete with $\mathrm{H}^{+}$ions for being adsorbed onto the surface of 


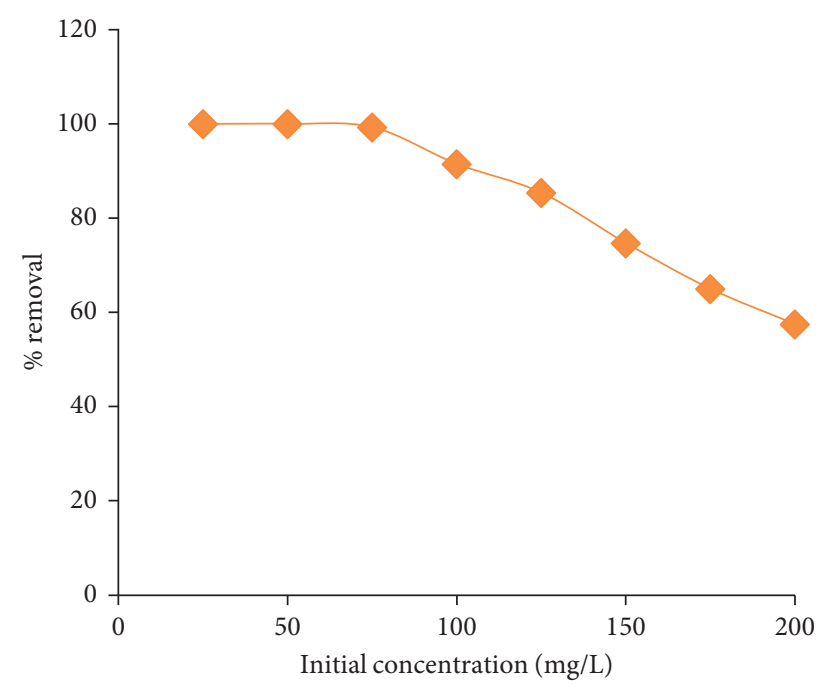

FIGURE 10: Effect of initial concentration on adsorption of lead.

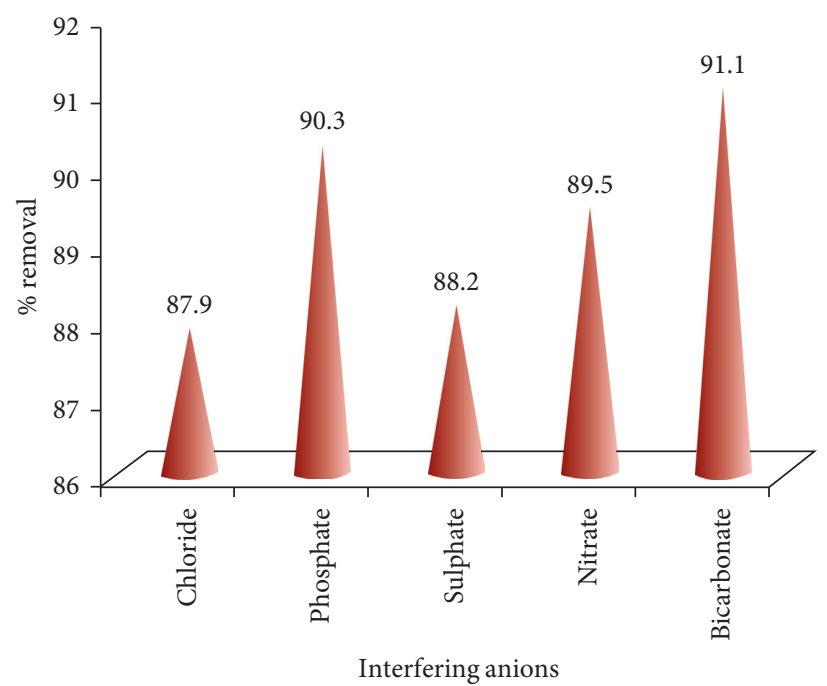

(a)

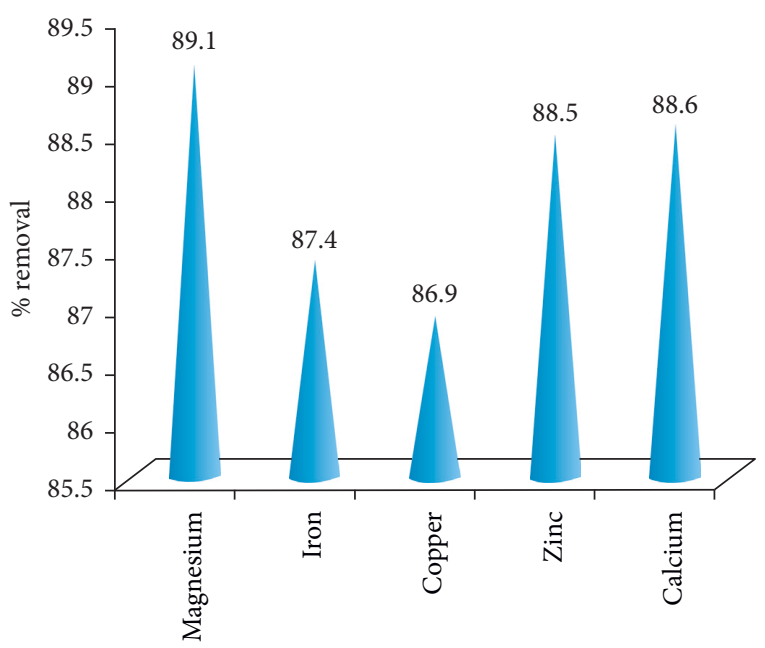

Interfering cations

(b)

FIgURE 11: (a) Effect of interfering anions on adsorption of lead. (b) Effect of interfering cations on adsorption of lead.

the adsorbent. As $\mathrm{H}^{+}$ions are more facile, the $\mathrm{Pb}^{2+}$ is less adsorbed, and hence, the \% removal is less. On other hand, as the $\mathrm{pH}$ is above 6 , the surface of the adsorbent acquires -ve charge. But the lead at $\mathrm{pH}$ above 8 is in the form of an anion $\mathrm{PbO}_{2}^{2-}$. Hence, the negative surface charge will repel $\mathrm{PbO}_{2}^{2-}$, and so, the \% removal is decreased. The maximum \% removal is found at $\mathrm{pH} 6$ when neutral conditions prevail on the surface of the adsorbent and lead is in cationic speciation.

3.2.2. Contact Time. The $\%$ removal of lead at different time intervals is shown in Figure 8. As seen from the figure, the extraction of lead increases from $58.4 \%$ to $91.5 \%$ until it reaches the steady state value $180 \mathrm{~min}$ with increase in time. After reaching the equilibrium state, the \% removal remains almost constant even when the agitation time is increased to $240 \mathrm{~min}$. Initially, rapid adsorption is occurred due to availability of more vacant sites. But with increase in time, the vacant sites are used up, and hence, the removal is slowed down.

3.2.3. Adsorbent Dosage. The variation of $\%$ removal with increase in the adsorbent dosage is investigated when all other extraction conditions are maintained at optimum levels. The results are presented in Figure 9. It can be noted that as the dosage increased from $0.5 \mathrm{~g}$ to $2.0 \mathrm{~g}$ of beads $/ 100 \mathrm{~mL}$, the \% removal is increased from $61.5 \%$ to $91.5 \%$, but after that, the \% removal remains constant. The optimum dosage is $2.0 \mathrm{~g} / 100 \mathrm{~mL}$ (in terms of beads).

3.2.4. Initial $\mathrm{Pb}^{2+}$ Concentration. By changing the initial concentration of $\mathrm{Pb}^{2+}$ from $25 \mathrm{mg} / \mathrm{L}$ to $200 \mathrm{mg} / \mathrm{L}$, but keeping all other extraction conditions at their optimum levels, the influence of $\mathrm{Pb}^{2+}$ initial concentration on the extraction of 


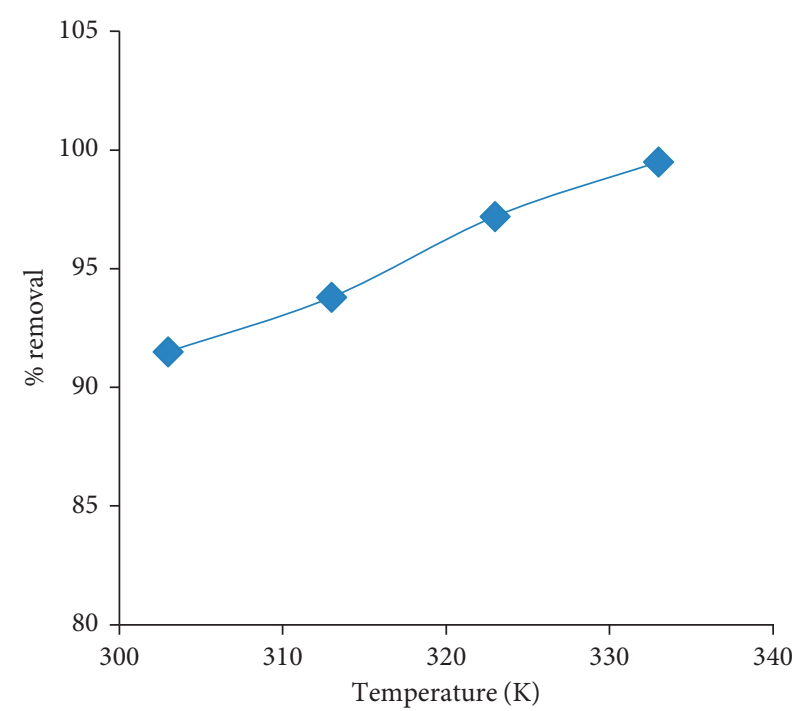

(a)

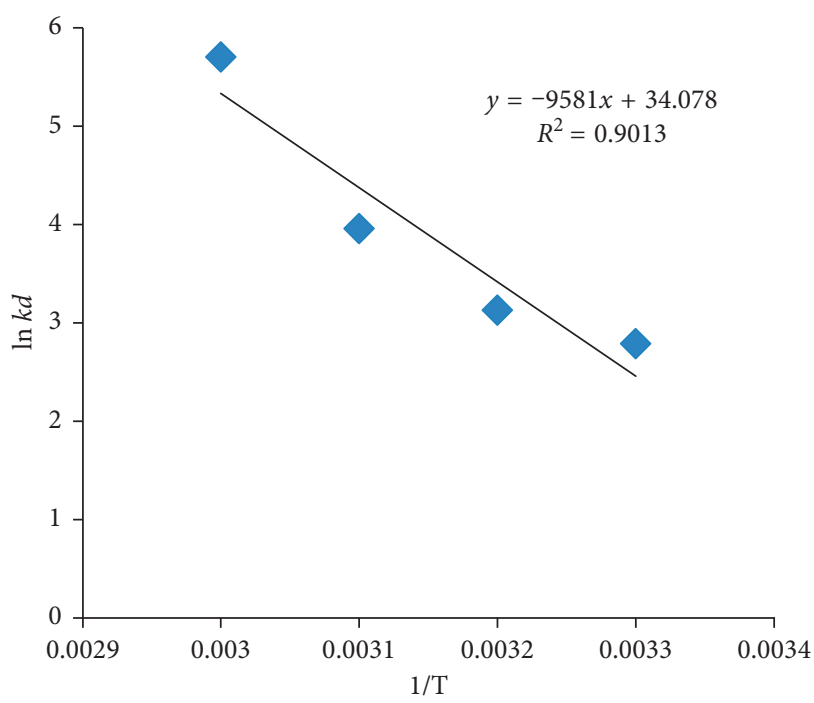

(b)

FIGURE 12: (a) Effect of interfering temperature on adsorption of lead. (b) Effect of interfering cations on adsorption of lead.

$\mathrm{Pb}^{2+}$ is investigated. The results are presented in Figure 10. It can be inferred from the figure that as the $\mathrm{Pb}^{2+}$ concentration increases from $25 \mathrm{mg} / \mathrm{L}$ to $200 \mathrm{mg} / \mathrm{L}$, the $\%$ removal decreases from $100.0 \%$ to $57.0 \%$.

At lower concentrations of lead ions, the availability of binding sites of the adsorbent (HRMCAB) is more, and hence, extraction of lead ions is more. With the fixed amount of adsorbent, only a definite amount of adsorption sites is available, and hence, as the initial concentration of lead ion increases, there is a multiple competition to secure the sorption sites, and this results in the decrease in the \% removal.

3.2.5. Co-Ions. The interference of commonly found co-ions (fivefold excess) in water on adsorption of the $\mathrm{Pb}^{2+}$ is studied, and the results are depicted in Figures 11(a) and 11(b).

It can be seen in the case of co-cations that the interference is of the order $\mathrm{Cu}^{2+}>\mathrm{Fe}^{3+}>\mathrm{Zn}^{2+}>\mathrm{Ca}^{2+}>\mathrm{Mg}^{2+}$. The interference in the case of anions is in the order $\mathrm{Cl}^{-}>\mathrm{SO}_{4}^{2-}>\mathrm{NO}_{3}^{-}>\mathrm{PO}_{4}^{3-}>\mathrm{HCO}_{3}^{-}$.

3.2.6. Thermodynamic Parameters. The effect of temperature on the $\%$ of extraction of $\mathrm{Pb}^{2+}$ is studied by increasing the temperature in the intervals of $10 \mathrm{~K}$ in the range 303 to $333 \mathrm{~K}$, while keeping all other conditions of extraction at optimum levels, namely, $\mathrm{pH}$ : 6 , contact time: $180 \mathrm{~min}$, initial concentration of lead: $100 \mathrm{mg} / \mathrm{L}, \mathrm{rpm}$ : 300, and adsorbent dosage: $20 \mathrm{~g} / \mathrm{L}$. The obtained results are presented in Figures 12 (a) and 12(b) and Table 2 . The $\%$ of extraction is found to be increased from $91.5 \%$ to $99.5 \%$ as the temperature increases from 303 to $333 \mathrm{~K}$.

Thermodynamic parameters, namely, enthalpy change $(\Delta H)(\mathrm{kJ} / \mathrm{mole})$, entropy change $(\Delta S)$, and free energy change $(\Delta G)(\mathrm{kJ} / \mathrm{mole})$, are evaluated at different temperatures using the equations $\Delta G^{0}=\Delta H^{0}-T \Delta S^{0} ; K_{d}=$ $q_{e} / C_{e}, \Delta G^{0}=-R T \ln K_{d} ; \ln K_{d}=\Delta S^{0} / R-\Delta H^{0} / R T$, where $C_{e}$ is the equilibrium concentration of lead ion solution, $q_{e}$ is the amount of adsorbed adsorbate $\mathrm{Pb}^{2+}, K_{d}$ is the distribution coefficient of the adsorption, $R$ is the gas constant, and $T$ is the absolute temperature in Kelvin as described in the literature $[30,31]$. The values obtained are presented in Table 2.

The positive $\Delta H$ value (79.656) indicates the endothermic and physisorption nature of the adsorption process. The negative $\Delta G$ values reflect that the nature of the adsorption is spontaneous. Moreover, the "+" value of $\Delta S$ reflects the increase in randomness at the boundary of solid and liquid during the equilibration leading to more adsorption of lead ions.

3.3. Adsorption Isotherms. Freundlich [32], Langmuir [33], Temkin [34], and Dubinin-Radushkevich [35] models related to adsorption equilibrium are investigated as described in the literature to understand the nature and mode of adsorption.

The linear equations used for Freundlich model is $\log \left(q_{e}\right)=\log k_{f}+(1 / n) \log C_{e}$ and for Langmuir model is $\left(C_{e} / q_{e}\right)=\left(a_{L} / k_{L}\right) C_{e}+1 / k L$, where $C_{e}, n$, and $q_{e}$ are adsorption capacity $(\mathrm{mg} / \mathrm{g})$, empirical parameter, and amount of $\mathrm{Pb}^{2+}$ adsorbed, respectively, and $k_{L}$ and $a_{L}$ are the Langmuir constants. The obtained results are presented in Figures 13(a) and 13(b) and Table 3. The dimensionless separation factor $\left(R_{L}\right)$ is calculated using the equation $R_{L}=$ $1 /\left(1+a_{L} C_{i}\right)$ [36]. $R_{L}$ values indicate the nature of adsorption: $R_{L}=1$, linear; $R_{L}>1$, unfavourable; $R_{L}=0$, irreversible; and $0<R_{L}<1$, favourable. The $R_{L}$ values of the present equilibration system are found to be between 0 and 1 (Table 3), and this indicated that lead ions are favourably adsorbed onto the surface of HRMCAB.

The $R^{2}$ values of Freundlich model and Langmuir model are 0.9662 and 0.9996 , respectively. This implies 


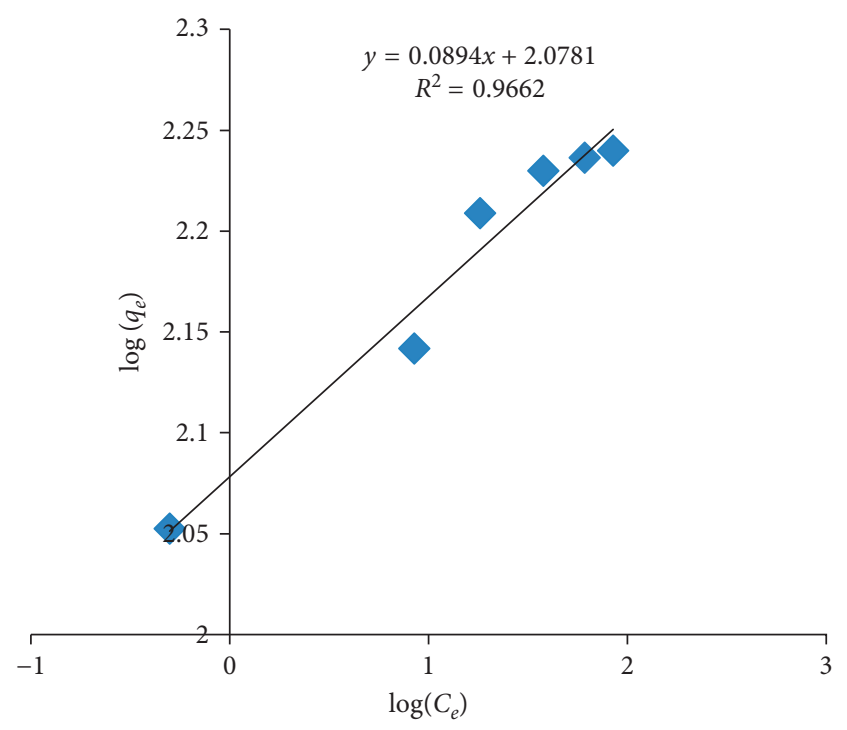

(a)

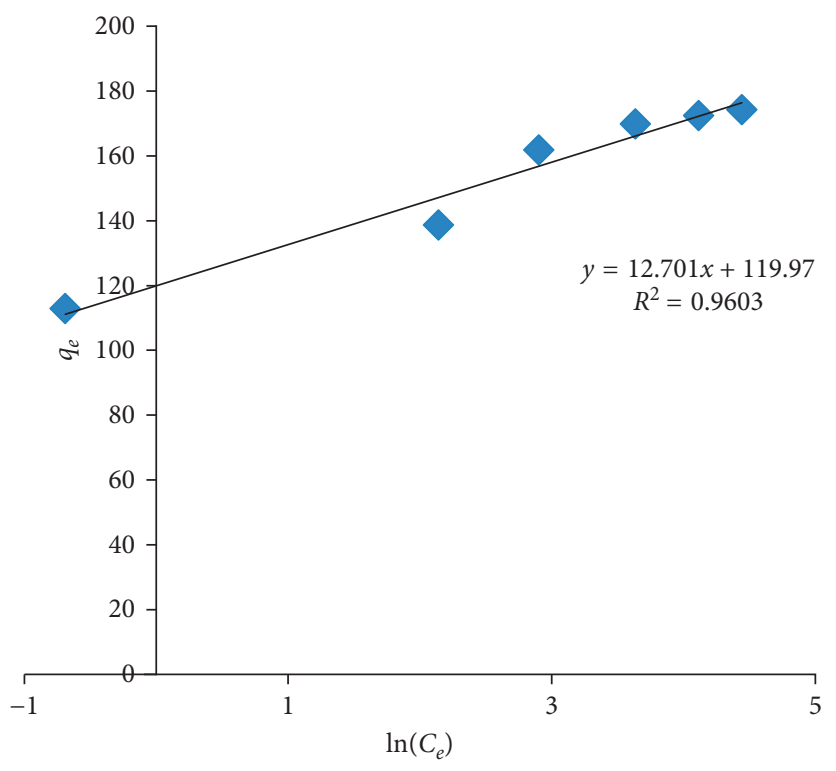

(c)

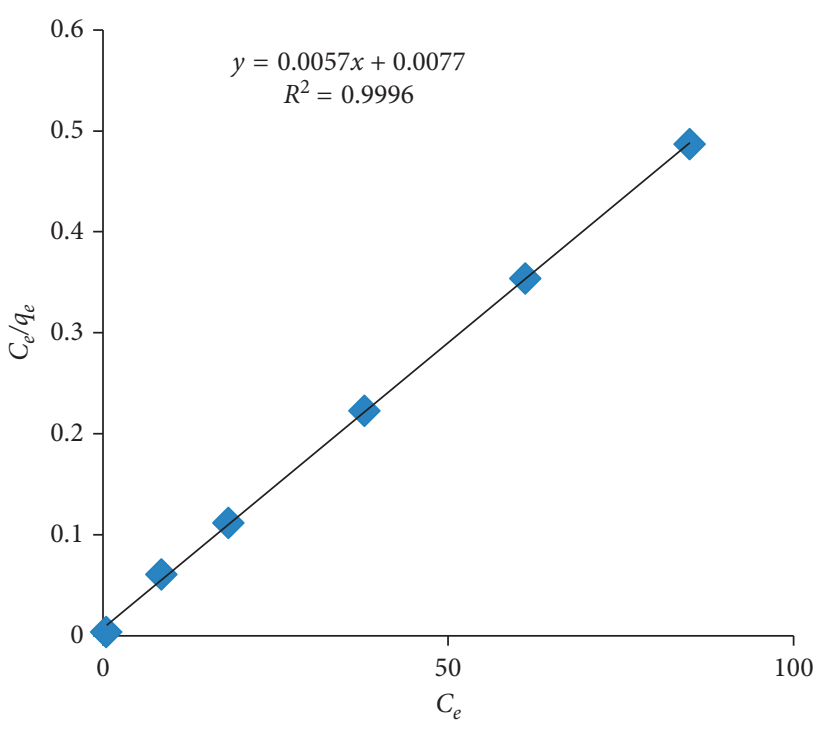

(b)

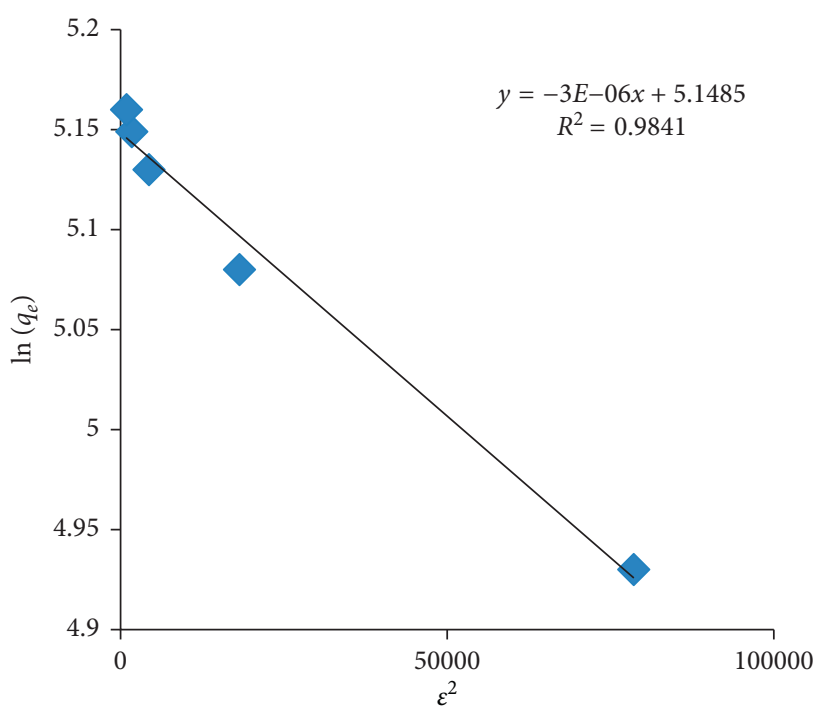

(d)

Figure 13: (a) Freundlich adsorption isotherm. (b) Langmuir adsorption isotherm. (c) Temkin adsorption isotherm. (d) DubininRadushkevich adsorption isotherm.

that Langmuir adsorption isotherm model is more acceptable, indicating the homogeneous nature of the adsorbent and the monolayer formation of lead onto the HRMCAB surface.

Further, Temkin and Dubinin-Radushkevich isotherms are also used in analysing the equilibrium process. Temkin equations used are $q_{e}=B \ln C_{e}+B \ln A$ and $B=R T / b$, where $A$ is the Temkin isotherm constant $(\mathrm{L} / \mathrm{g}), B$ is the heat of sorption $(\mathrm{J} / \mathrm{mol}), b$ is the Temkin isotherm constant, $T$ is the temperature $(k)$, and $R$ is the gas constant.

Linear form of Dubinin-Radushkevich equation is $\ln q_{e}=-\beta \varepsilon^{2}+\ln q_{m}$, where $\varepsilon=R T \ln \left(1+1 / C_{e}\right), \beta$ is the energy constant, and $q_{m}$ is the Dubinin-Radushkevich monolayer adsorption capacity $(\mathrm{mol} / \mathrm{g})$. The linear plots of these two isotherms are presented in Figures 13(c) and 13(d), and the correlation coefficient and isothermal constants are presented in Table 3. By using the formula $E=1 / \sqrt{2} \beta$ and by the slope of the Temkin isotherm constants, the heat of sorption $(B)$ and mean free energy $(E)$ are calculated. As $E$ is $<8 \mathrm{~kJ} / \mathrm{mol}$ (i.e., 0.408 ) and $B$ is $<20 \mathrm{~kJ} / \mathrm{mol}$ (i.e., 12.701 ), the mechanism of adsorption is "physisorption" in nature, that is, nonspecific adsorption attributed to the weak Van der Waals forces between HRMCAB and lead ions. 


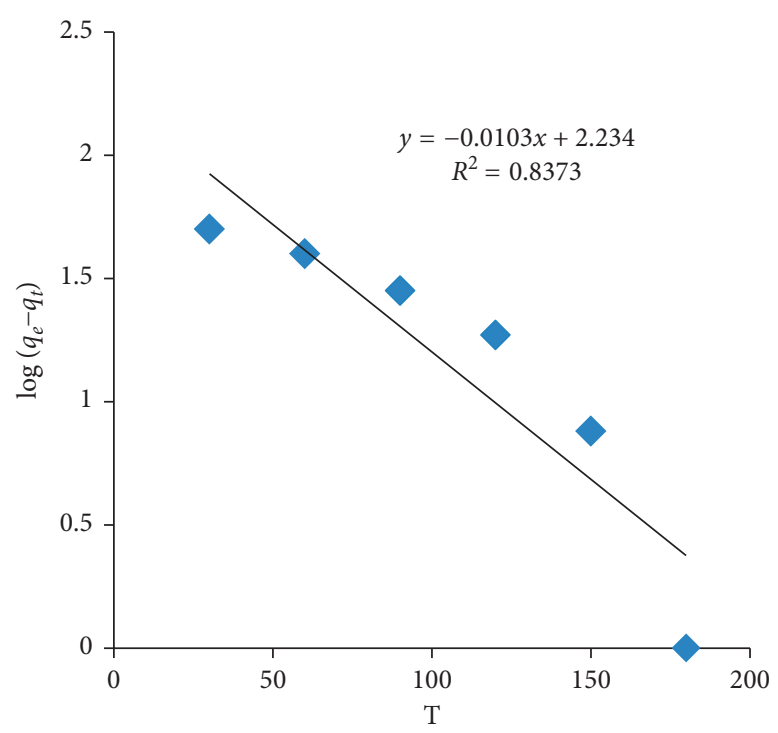

(a)

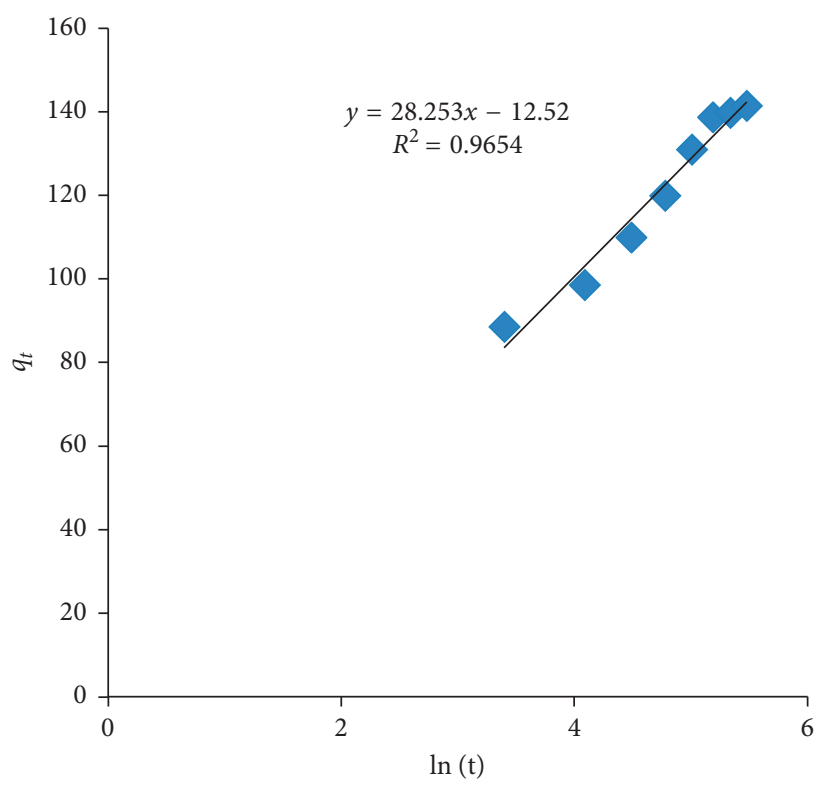

(c)

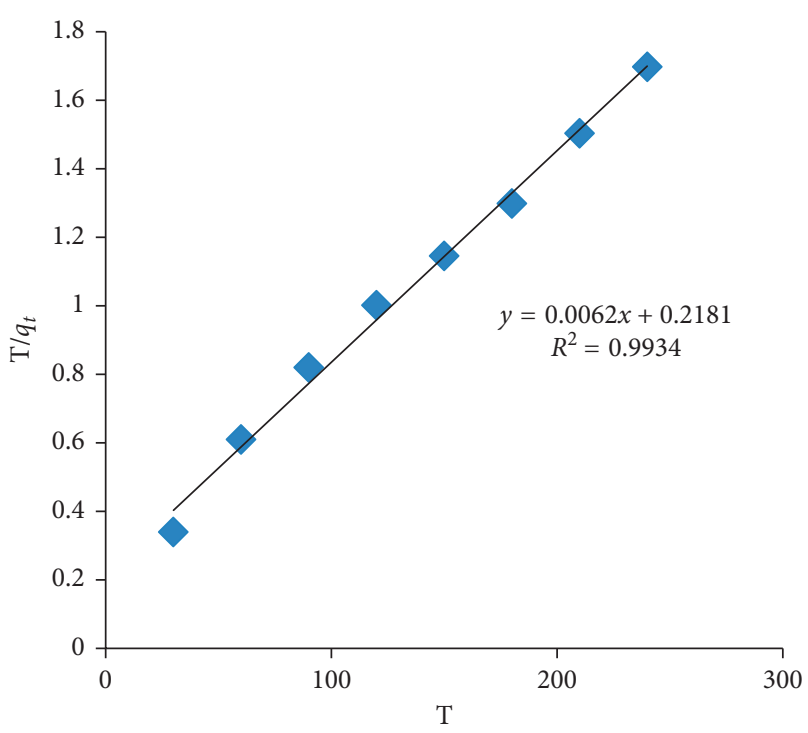

(b)

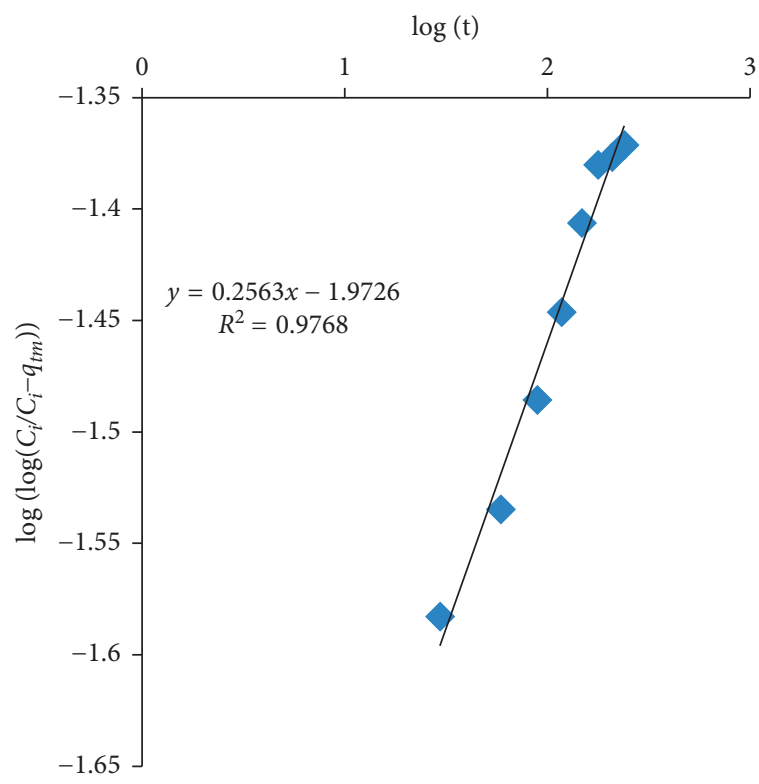

(d)

Figure 14: (a) Pseudo-first-order kinetics. (b) Pseudo-second-order kinetics. (c) Elovich model. (d) Bangham's pore diffusion model.

3.4. Kinetics of Adsorption. The adsorption kinetics are analysed by using pseudo-first order: $\log \left(q_{e}-q_{t}\right)=\log q_{e}-K_{1}$ / $2.303 t$ [37], pseudo-second order: $t / q_{t}=1 / K_{2} q_{e}^{2}+1 / q_{e} t$ [38], Bangham's pore diffusion model: $\log \left[\log \left(C_{i} / C_{i}-q_{t} m\right)\right]=$ $\log \left(K_{o} / 2.303 V\right)+\propto \log (t)$ [39], and Elovich equation: $q_{t}=$ $1 / \beta \ln (\propto \beta)+1 / \beta \ln (t)$ [40]. The results are presented in Figures 14(a)-14(d) and Table 4. The correlation coefficient value $\left(R^{2}\right)$ is found to be in the following order: pseudo-second order (0.9934) $>$ Bangham's pore diffusion model (0.9768) $>$ Elovich model (0.9654) > pseudo-first order (0.8373). Hence, the pseudo-second-order model is better fit to explain the adsorption process.
3.5. Applications. The methodology developed in the present work is applied to the effluent samples collected at lead-based industries. The results are presented in Table 5. It can be inferred from the table that substantial amounts of lead can be removed from the industrial samples.

3.6. Comparison. The adsorption ability of the adsorbent developed in this work is compared against various hitherto reported adsorbents in the literature as presented in Table 6. It may be inferred that the present developed 
TABLE 5: Lead concentration (before and after) of samples (samples collected from the effluents of lead-based industries in Andhra Pradesh, India).

\begin{tabular}{lcccc}
\hline S. number & Water samples & $C_{i}(\mathrm{mg} / \mathrm{l})$ (initial concentration of lead ions) & $C_{f}(\mathrm{mg} / \mathrm{l})$ (final concentration of lead ions) & $\%$ removal \\
\hline$(1)$ & Sample 1 & 4.24 & 0.42 & $89.9 \%$ \\
$(2)$ & Sample 2 & 3.62 & 0.27 & $92.4 \%$ \\
$(3)$ & Sample 3 & 2.89 & 0.16 & $94.3 \%$ \\
$(4)$ & Sample 4 & 2.06 & 0.06 & $96.7 \%$ \\
\hline
\end{tabular}

TABLE 6: Comparison of maximum adsorption capacity of the adsorbent with other adsorbents from the literature.

\begin{tabular}{|c|c|c|c|c|}
\hline S. number & Adsorbent & $\mathrm{pH}$ & $q_{e}(\mathrm{mg} / \mathrm{g})$ & Reference \\
\hline (1) & HRMCAB & 6.0 & 138.63 & Present work \\
\hline (2) & $\mathrm{HCl}$-activated red mud & 4.0 & 6.207 & Kumar Sahu et al. [19] \\
\hline (3) & $\mathrm{H}_{2} \mathrm{O}_{2}$-treated red mud & 4.0 & 64.79 & Gupta et al. [20] \\
\hline (4) & Red mud coagulant & 7.0 & 98.695 & Kong [21] \\
\hline (5) & Fluted pumpkin seed shell active carbon & - & 14.286 & Okoye et al. [41] \\
\hline (6) & Pine cone-activated carbon & 6.7 & 27.53 & Momčilović et al. [42] \\
\hline (7) & Coconut shell carbon & - & 30.0 & Sekhar [43] \\
\hline (8) & Zinc chloride-activated tamarind wood & 6.5 & 43.85 & Acharyaa et al. [44] \\
\hline (9) & Poly(acrylic acid)/bentonite nanocomposite & - & 93.0 & Rafiei et al. [45] \\
\hline$(10)$ & Magnetic magnetite $\left(\mathrm{Fe}_{3} \mathrm{O}_{4}\right)$ nanoparticle & 5.0 & 53.11 & Rajput et al. [46] \\
\hline
\end{tabular}

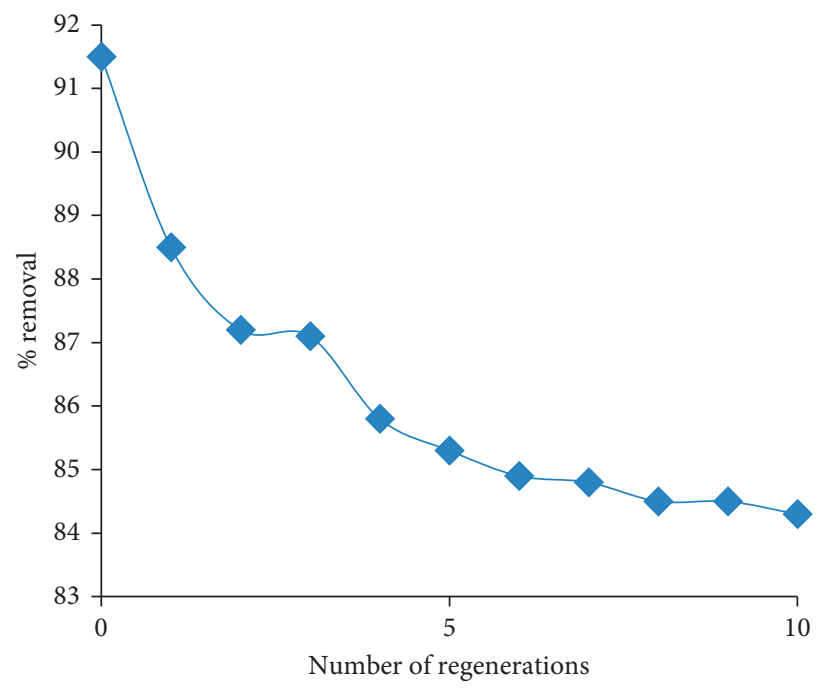

FIgURE 15: Number of regenerations versus \% removal.

adsorbent has good adsorption ability than many adsorbents developed so far, and further, the immobilization of the hydrazine sulphate-treated red mud in calcium alginate beads renders the filtration easy.

3.7. Regeneration and Reuse. Of the various leaching agents tried for the extraction of lead from the adsorbent, $0.1 \mathrm{M} \mathrm{HCl}$ is found to be good and hence adopted in this work.
A number of regenerations of the adsorbent are made, and thus regenerated adsorbents are used for the removal of lead. The results obtained are presented in Figure 15. It is seen that, as the number of regenerations increases, the adsorption nature decreases. But even with 10th regenerated adsorbent, $\mathrm{Pb}^{2+}$ is successfully removed to an extent of $84.3 \%$. Hence, by repetitive use of the regenerated adsorbent, the lead can be completely removed from water samples at the comfortable natural water $\mathrm{pH}$ 6. This indicates that the present developed methodology is successful. 


\section{Conclusions}

Hydrazine sulphate-activated red mud doped in calcium alginate beads (HRMCAB) are prepared and are used as sorbent to extract lead ions from water by optimising various physicochemical parameters. Batch methods of extractions are adopted. $91.5 \%$ of lead is found to be removed from simulated water at $\mathrm{pH} 6$, sorbent dosage of $0.066 \mathrm{~g}$ of red mud (doped in $2.0 \mathrm{~g}$ of HRMCAB beads)/100 mL, agitation time of $180 \mathrm{~min}$, initial concentration of $100 \mathrm{mg} / \mathrm{L}, 300 \mathrm{rpm}$, and $303 \mathrm{~K}$ temperature. The adsorption capacity of HRMCAB is $138.63 \mathrm{mg} / \mathrm{g}$. The interference of the co-cations is of the order $\mathrm{Cu}^{2+}>$ $\mathrm{Fe}^{3+}>\mathrm{Zn}^{2+}>\mathrm{Ca}^{2+}>\mathrm{Mg}^{2+}$ while the anions interfered in the order $\mathrm{Cl}^{-}>\mathrm{SO}_{4}^{2-}>\mathrm{NO}_{3}^{-}>\mathrm{PO}_{4}^{3-}>\mathrm{HCO}_{3}^{-}$.

Surface morphological studies adopting FTIR, FESEM, and EDX confirm that lead is onto the surface of the adsorbent. By evaluating thermodynamic parameters, it is inferred that the sorption process is spontaneous and "physisorption" in nature.

On analysis of the various adsorption isotherms, the adsorption follows the Langamuir isotherm model, thereby confirming the homogeneous surface of the adsorbent and monolayer formation. Further, adsorption kinetics is analysed adopting various models, and it is observed that it follows pseudo-second order with $R^{2}=0.9934$.

By immobilizing the activated red mud in the beads, the filtration process is made easy. Successive regeneration of the adsorbent with $0.1 \mathrm{M} \mathrm{HCl}$ has not markedly affected the adsorption nature of the adsorbent. Even after 10 cycles of regeneration of the adsorbent, substantial amount of lead is removed to an extent of $83.4 \%$. Hence, by repetitive use of the same adsorbent, it is possible to remove lead completely from the water. Further, the immobilization of activated red mud in the beads facilitated the easy filtration. The methodology developed is successfully applied for removing lead from industrial waste waters.

\section{Conflicts of Interest}

The authors declare that there are no conflicts of interest.

\section{Acknowledgments}

The authors thank the Ministry of Environment and Forests (MOEF), New Delhi, for granting the project entitled "Red mud as an adsorbent for the removal of pollutants" (File no. $19 / 16 / 2014-\mathrm{RE})$, and under whose financial aid, this work has been carried out.

\section{References}

[1] T. G. Kazi, N. Jalbani, N. Kazi et al., "Evaluation of toxic metals in blood and urine samples of chronic renal failure patients, before and after dialyses," Renal Failure, vol. 30, no. 7, pp. 737-745, 2008.

[2] H. I. Afridi, T. G. Kazi, G. H. Kazi, M. K. Jamali, and G. Q. Shar, "Essential trace and toxic element distribution in the scalp hair of Pakistani myocardial infarction patients and controls," Biological Trace Element Research, vol. 113, no. 1, pp. 19-34, 2006.

[3] Y. P. Teoh, M. A. Khan, and T. S. Y. Choong, "Kinetic and isotherm studies for lead adsorption from aqueous phase on carbon coated monolith," Chemical Engineering Journal, vol. 217, pp. 248-255, 2013.

[4] O. Sree Devi and K. Ravindhranath, "Control of chromate in polluted waters: a biological approach," Indian Journal of Environment Protection, vol. 32, no. 11, pp. 943-951, 2012.

[5] A. Naga Babu, G. V. Krishna Mohan, and K. Ravindhranath, "Removal of Chromium (VI) from polluted waters using adsorbents derived from Chenopodium album and Eclipta prostrate plant materials," International Journal of ChemTech Research, vol. 9, no. 3, pp. 506-516, 2016.

[6] K. Papodu, Y. Hanumantha Rao, and K. Ravindhranath, "Removal of Zinc from waste waters using new biosorbents derived from Terminalia arjuna, Atlantaia monophylla $(L)$ Correa and Madhuca indica plants," Der Pharma Chemica, vol. 6, no. 6, pp. 19-34, 2014.

[7] A. A. Kumari and K. Ravindhranath, "Extraction of Aluminum (III) ions from polluted waters using bio-sorbents derived from Acacia melanoxylon and Eichhornia crassipes plants," Journal of Chemical and Pharmaceutical Research, vol. 4, no. 5, pp. 2836-2849, 2012.

[8] S. Ravulapalli and R. Kunta, "Defluoridation studies using active carbon derived from the barks of Ficus racemosa plant," Journal of Fluorine Chemistry, vol. 193, pp. 58-66, 2017.

[9] M. Suneetha, B. Syama Sundar, and K. Ravindhranath, "Assessment of ground water quality and application of activated carbons in the removal of fluoride from ground waters of Vinukonda Mandal in Guntur District, Andhra Pradesh, India," Der Pharma Chemica, vol. 6, no. 6, pp. 56-67, 2014.

[10] M. Suneetha and K. Ravindhranath, "Extractability of nitrites from polluted waters using bio-sorbents derived from leaves, barks or stems of some herbal plants," Journal of Chemical and Pharmaceutical Research, vol. 6, no. 8, pp. 408-420, 2014.

[11] K. Prameela Rani and K. Ravindhranath, "The use of bioadsorbents derived from Cassia auriculata, Celastrus paniculata and Carmona retusa in the removal of Ammonia from polluted waters," Der Pharma Chemica, vol. 6, no. 3, pp. 56-63, 2014.

[12] Y. Hanumantha Rao and K. Ravindhranath, "New methodologies in phosphate pollution control: using bio-sorbents derived from Terminalia arjuna and Madhuca indica plants," International Journal of ChemTech Research, vol. 8, no. 12, pp. 784-796, 2015.

[13] S. K. Karimulla and K. Ravindhranath, "Extraction of methyl orange dye from polluted waters using bio-sorbents derived from Thespesia populnea and Pongamia pinnata plants," Der Pharma Chemica, vol. 6, no. 4, pp. 333-344, 2014.

[14] S. Zhang, C. Liu, Z. Luana, X. Peng, H. Rena, and J. Wang, "Arsenate removal from aqueous solutions using modified red mud," Journal of Hazardous Materials, vol. 152, no. 2, pp. 486-492, 2008.

[15] H. Nadaroglu and E. Kalkan, "Removal of cobalt (II) ions from aqueous solution by using alternative adsorbent industrial red mud waste material," International Journal of Physical Sciences, vol. 7, no. 9, pp. 1386-1394, 2012.

[16] S. Ramesh Chandra, P. Rajkishore, and B. Chandra Ray, "Adsorption of $\mathrm{Zn}(\mathrm{II})$ on activated red mud: neutralized by $\mathrm{CO}_{2}$," Desalination, vol. 266, no. 1-3, pp. 93-97, 2011.

[17] G. V. Krishna Mohan, A. Naga Babu, K. Kalpana, and K. Ravindhranath, "Removal of naphthol green B dye from 
polluted waters using hydrogen peroxide treated red mud," Der Pharma Chemica, vol. 8, no. 19, pp. 403-414, 2016.

[18] G. V. Krishna Mohan, A. Naga Babu, K. Kalpana, and K. Ravindhranath, "Activated red mud as an adsorbent in the removal of anionic dye, brilliant yellow dye, from polluted waters," International Journal of ChemTech Research, vol. 9, no. 11, pp. 1-15, 2016.

[19] M. Kumar Sahu, S. Mandal, S. S. Dash, P. Badhai, and R. Kishore Patel, "Removal of $\mathrm{Pb}$ (II) from aqueous solution by acid activated red mud," Journal of Environmental Chemical Engineering, vol. 1, no. 4, pp. 1315-1324, 2013.

[20] V. K. Gupta, M. Gupta, and S. Sharma, "Process development for the removal of lead and chromium from aqueous solutions using red mud an aluminium industry waste," Water Research, vol. 35, no. 5, pp. 1125-1134, 2001.

[21] C.-Y. Kong, "Adsorption characteristics of activated red mud for lead removal," Asian Journal of Chemistry, vol. 23, no. 5, pp. 1963-1965, 2011.

[22] V. Orescanin, D. Tibljas, and V. Valkovic, "A study of coagulant production from red mud and its use for heavy metals removal," Journal of Trace and Microprobe Techniques, vol. 20, no. 2, pp. 233-245, 2002.

[23] G. V. Krishna Mohan, A. Naga Babu, K. Kalpana, and K. Ravindhranath, "Zirconium-treated fine red mud impregnated in $\mathrm{Zn}$-alginate beads (ZRMAB) as an adsorbent in removal of phosphate from water," Asian Journal of Chemistry, vol. 29, no. 11, pp. 2549-2558, 2017.

[24] Y. Yu, Z. Hu, Z. Chen, J. Yang, H. Gao, and Z. Chen, "Organically-modified magnesium silicate nano composites for high-performance heavy metal removal," RSC Advances, vol. 6, no. 100, pp. 97523-97531, 2016.

[25] G. Newcombe, R. Hayes, and M. Drikas, "Granular activated carbon: importance of surface properties in the adsorption of naturally occurring organics," Colloids and Surfaces A: Physicochemical and Engineering Aspects, vol. 78, pp. 65-71, 1993.

[26] K. Kadirvelu, C. Faur-Brasquet, and P. Le Cloirec, "Removal of $\mathrm{Cu}(\mathrm{II}), \mathrm{Pb}(\mathrm{II})$, and $\mathrm{Ni}(\mathrm{II})$ by adsorption onto activated carbon cloths," Langmuir, vol. 16, no. 22, pp. 8404-8409, 2000.

[27] Metcalf and Eddy, Inc., Wastewater Engineering: Treatment of Reuse, McGraw-Hill, New York, NY, USA, 4th edition, 2003.

[28] G. Kiely, Environmental Engineering, McGraw-hall International Editions, New York, NY, USA, 1998.

[29] A. R. K. Trivedy, Pollution Management in Industries, Environmental Publications, Karad, India, 2nd edition, 1995.

[30] G. Karthikeyan and S. Siva Elango, "Fluoride sorption using Morringa Indicabased activated carbon," Journal of Environmental Health Science \& Engineering, vol. 4, no. 1, pp. 21-28, 2007.

[31] G. Alagumuthu and M. Rajan, "Equilibrium and kinetics of adsorption of fluoride onto zirconium impregnated cashew nut shell carbon," Chemical Engineering Journal, vol. 158, no. 3, pp. 451-457, 2010.

[32] H. M. F. Freundlich, "Over the adsorption in solution," The Journal of Physical Chemistry, vol. 57, pp. 385-471, 1906.

[33] I. Langmuir, "The adsorption of gases on plane surfaces of glass, mica and platinum," Journal of the American Chemical Society, vol. 40, no. 9, pp. 1361-1368, 1918.

[34] M. J. Temkin and V. Pyzhev, "Recent modifications to Langmuir isotherms," Acta Physico-Chimica Sinica, USSR, vol. 12, pp. 217-222, 1940.

[35] M. M. Dubinin and L. V. Radushkevich, "The equation of the characteristic curve of the activated charcoal," Proceedings of the Academy of Sciences, Physical Chemistry, Section, USSR, vol. 55, pp. 331-333, 1947.

[36] K. R. Hall, L. C. Eagleton, A. Acrivos, and T. Vermevlem, "Pore and solid diffusion kinetics in fixed bed adsorption under constant pattern conditions," Industrial \& Engineering Chemistry Fundamentals, vol. 5, no. 12, pp. 212-219, 1966.

[37] J. F. Corbett, "Pseudo first-order kinetics," Journal of Chemical Education, vol. 49, no. 10, p. 663, 1972.

[38] Y. S. Ho and G. McKay, "Pseudo-second order model for sorption processes," Process Biochemistry, vol. 34, no. 5, pp. 451-465, 1999.

[39] Y. S. Ho, J. C. Y. Ng, and G. McKay, "Kinetics of pollutant sorption by biosorbents: review," Separation and Purification Methods, vol. 29, no. 2, pp. 189-232, 2000.

[40] S. Lagergren, "About the theory of so-called adsorption of soluble substances," Kungliga Svenska, Vetenskapsakademiens, Handlingar, vol. 24, no. 4, pp. 1-39, 1898.

[41] A. I. Okoye, P. M. Ejikeme, and O. D. Onukwuli, "Lead removal from wastewater using fluted pumpkin seed shell activated carbon: adsorption modelling and kinetics," International Journal of Environmental Science \& Technology, vol. 7, no. 4, pp. 793-800, 2010.

[42] M. Momčilović, M. Purenović, A. Bojić, A. Zarubica, and M. Ranđelović, "Removal of lead(II) ions from aqueous solutions by adsorption onto pine cone activated carbon," Desalination, vol. 276, no. 1-3, pp. 53-59, 2011.

[43] M. C. Sekhar, "Removal of lead from aqueous effluents by adsorption on coconut shell carbon," Journal of Environmental Science \& Engineering, vol. 50, no. 2, pp. 137-140, 2008.

[44] J. Acharyaa, J. N. Sahub, C. R. Mohantyc, and B. C. Meikap, "Removal of lead(II) from wastewater by activated carbon developed from Tamarind wood by zinc chloride activation," Chemical Engineering Journal, vol. 149, no. 1-3, pp. 249-262, 2009.

[45] H. R. Rafiei, M. Shirvani, and O. A. Ogunseitan, "Removal of lead from aqueous solutions by a poly(acrylic acid)/bentonite nanocomposite," Applied Water Science, vol. 6, no. 4, pp. 331-338, 2014.

[46] S. Rajput, C. U. Pittman Jr., and D. Mohan, "Magnetic magnetite $\left(\mathrm{Fe}_{3} \mathrm{O}_{4}\right)$ nanoparticle synthesis and applications for lead $\left(\mathrm{Pb}^{2+}\right)$ and chromium $\left(\mathrm{Cr}^{6+}\right)$ removal from water," Journal of Colloid and Interface Science, vol. 468, pp. 334-346, 2016. 

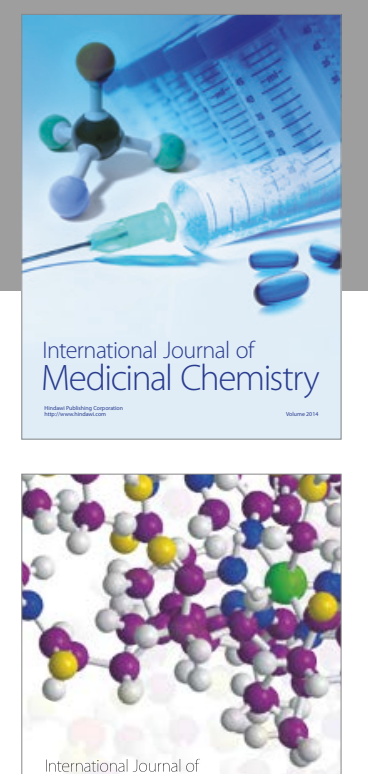

Carbohydrate Chemistry

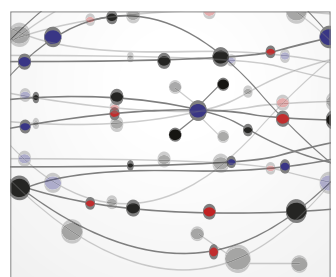

The Scientific World Journal
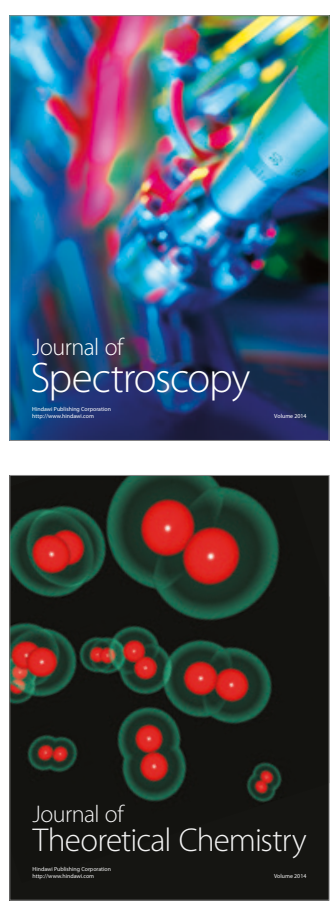
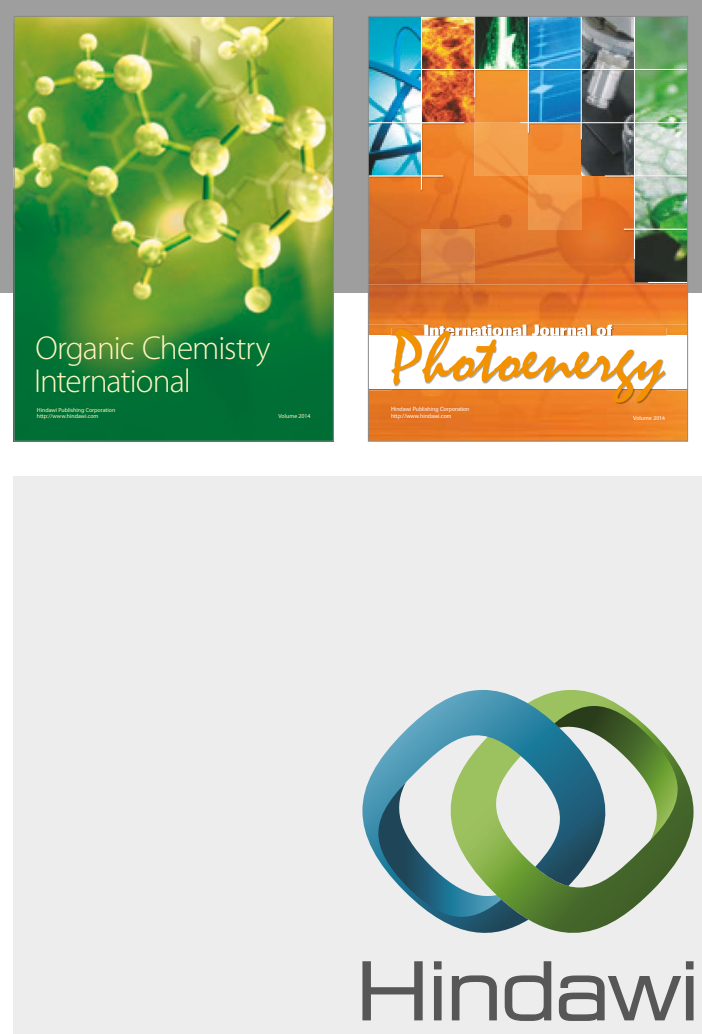

Submit your manuscripts at

https://www.hindawi.com

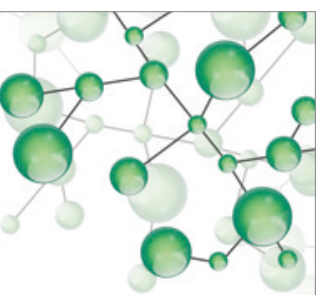

International Journal of

Inorganic Chemistry

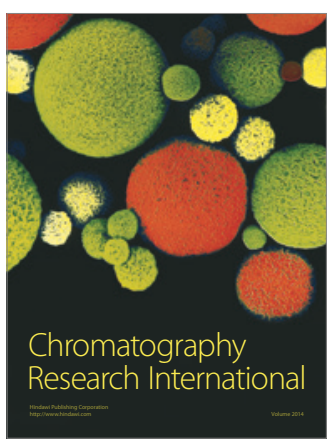

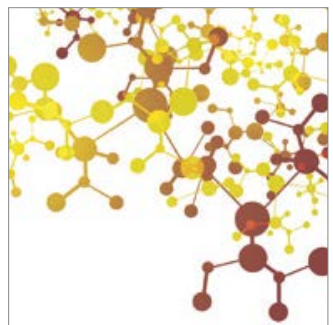

Applied Chemistry
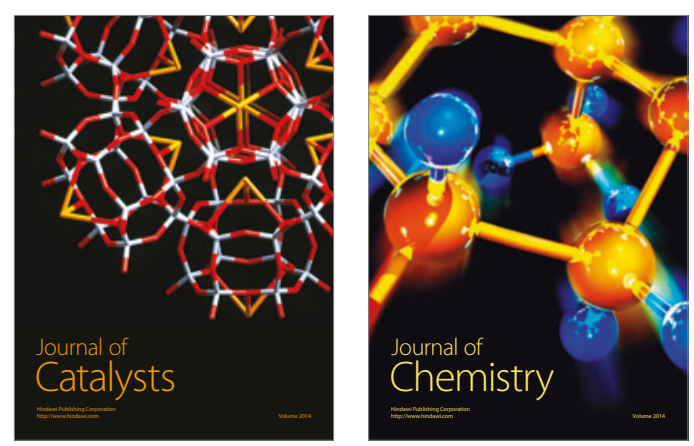
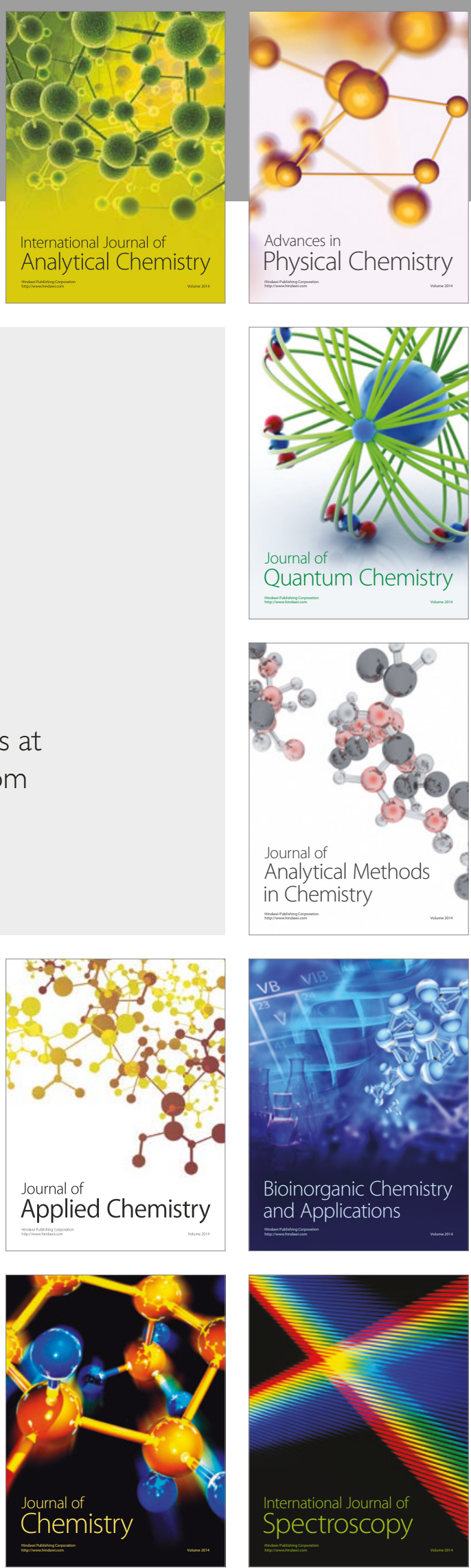